\title{
KONTRIBUSI PERBANKAN SYARIAH TERHADAP PEREKONOMIAN BANTEN
}

\author{
Zaini Ibrahim \\ IAIN Sultan Maulana Hasanuddin Banten
}

\begin{abstract}
Abstrak. Kontribusi Perbankan Syariah Terhadap Perekonomian Banten. Perkembangan perbankan syariah di Banten dapat dilihat dari empat aspek, yaitu jumlah aset, DPK, pembiayaan dan resiko kredit. Meski terus menunjukkan perkembangan yang baik, namun kinerja perbankan syariah terhadap total perbankan di wilayah Banten masih relatif kecil. Sampai triwulan IV 2013, pangsa aset perbankan syariah di Banten baru mencapai 6,78 persen dari total aset perbankan di wilayah Provinsi Banten. Demikian juga dengan pangsa penghimpunan DPK perbankan syariah hanya sebesar 5,20 persen. Sementara itu pembiayaan yang disalurkan oleh perbankan syariah di Provinsi Banten hanya sebesar 7,61 persen dari total kredit perbankan di Provinsi Banten. Penelitian ini dilakukan dengan maksud untuk mengetahui kontribusi perbankan syariah terhadap peningkatan PDRB Provinsi Banten. Riset ini menggunakan 60 sampel, meliputi data bulanan sejak Januari 2009 sampai Desember 2013 terdiri dari PDRB Banten, DPK dan pembiayaan perbankan syariah di Banten. Teknik analisis data menggunakan regresi linier berganda dengan bantuan software eviews. Hasil pengolahan data menunjukkan bahwa DPK dan pembiayaan tidak berpengaruh secara parsial terhadap peningkatan PDRB Banten. Namun DPK dan pembiayaan secara bersama-sama/ simultan berpengaruh terhadap PDRB Banten. Angka koefisien determinasi sebesar 53\% menunjukkan nilai kontribusi perbankan syariah, dan umumnya sektor keuangan, terhadap kemajuan perekonomian Banten. Sisanya 47\% disumbangkan oleh sektor lain yang tidak dimasukkan dalam penelitian ini. Tingginya kontribusi perbankan syariah terhadap perekonomian Banten harus direspon dengan penyiapan infrastruktur yang memadai, terutama berkaitan dengan peningkatan kualitas dan kuantitas sumber daya manusia yang menguasai bidang ekonomi dan keuangan Islam. Diperlukan juga dorongan untuk Pemprov Banten agar meningkatkan proporsi penempatan dana desentralisasi di lembaga keuangan syariah.
\end{abstract}

Kata Kunci: Pertumbuhan, ekonomi, Banten, PDRB, bank syariah.

Abstract. The Contribution of Islamic Banking on the Banten Economy. The development of Islamic banking in Banten can be seen from the four aspects, such as amount of assets, DPK, financing and credit risks. Even indicates the good growth, but the performance of Islamic banking from the total banking in Banten region is still relatively small. Until the fourth quarter of 2013, the share of Islamic banking assets in Banten only reached 6.78 percent of total banking assets in the province of Banten. Likewise, the share of Islamic banking on third party funds amounted only 5.20 percent. While the financing extended by the Islamic banking in Banten province amounted only 7.61 percent of total bank credit in Banten Province. This research was conducted with a view to determine the contribution of Islamic banking to increase PDRB Banten Province. This research uses 60 samples, including monthly data from January 2009 
until December 2013 consisted of PDRB Banten, DPK and financing Islamic banking in Banten. The data were analyzed using multiple linear regression with the help of software eviews. The results showed that the DPK data processing and financing not partial effect on PDRB increase in Banten. However DPK and financing jointly/ simultaneous effect on PDRB Banten. Figures determination coefficient of 53\% shows the value of the contribution of Islamic banking and finance sector generally, to the economic progress of Banten. The remaining 47\% was contributed by other sectors that are not included in this study. The high contribution of Islamic banking to Banten's economy must be supported by the preparation of adequate infrastructure, especially concerned to improve the quality and quantity of human resources in the Islamic economics and finance area. Beside that, we must give the encouragement to the government of Banten in order to increase the proportion of decentralized funds placement in Islamic financial institutions.

Key Words: growth, economy, Banten, PDRB, Islamic banking. 


\section{PENDAHULUAN}

Pertumbuhan perbankan syariah secara nasional tidak lain ditopang oleh pertumbuhan bank syariah di daerah, misalnya Provinsi Banten. Perkembangan perbankan syariah di Banten dapat dilihat dari empat aspek, yaitu jumlah aset, DPK, pembiayaan dan resiko kredit. Total aset perbankan syariah di Banten di akhir tahun 2013 mengalami peningkatan menjadi Rp 8,313 triliun, meningkat sekitar Rp 600 miliar dibandingkan akhir tahun 2012 yang mencapai Rp 7,715 triliun. DPK yang berhasil dihimpun oleh perbankan syariah mengalami sedikit penurunan sekitar Rp 54 miliar, dari yang semula Rp 5,537 triliun di Desember 2012 menjadi Rp 5,483 triliun di Desember 2013. Demikian juga dengan perkembangan pembiayaan yang tumbuh positif lebih dari 23 persen dari yang semula Rp 4,698 triliun menjadi Rp 5,803 triliun. Sementara itu, kualitas pembiayaan yang diwakili oleh non performing financing (NPF) berada pada level 1,53 persen di akhir tahun 2013.

Meski terus menunjukkan perkembangan yang baik, namun kinerja perbankan syariah terhadap total perbankan di wilayah Banten masih relatif kecil, seperti terlihat dari pangsa beberapa indikator seperti aset, DPK, dan pembiayaan. Sampai triwulan IV 2013, pangsa aset perbankan syariah di Banten baru mencapai 6,78 persen dari total aset perbankan di wilayah Provinsi Banten. Demikian juga dengan pangsa penghimpunan DPK perbankan syariah hanya sebesar 5,20 persen. Sementara itu pembiayaan yang disalurkan oleh perbankan syariah di Provinsi Banten hanya sebesar 7,61 persen dari total kredit perbankan di Provinsi Banten (Data KER Banten, 2013).

Besarnya peran sektor perbankan dalam memajukan perekonomian daerah tidak bisa diragukan lagi, termasuk di dalamnya keterlibatan perbankan syariah. Berdasarkan uraian di atas, penulis tertarik melakukan penelitian untuk mengetahui kontribusi perbankan syariah terhadap peningkatan PDRB Provinsi Banten. Secara lebih spesifik, judul penelitian dirumuskan sebagai berikut: Kontribusi Perbankan Syariah Bagi Perekonomian Banten. Judul tersebut di-breakdown menjadi sebuah masalah penelitian yaitu, berapa besar kontribusi yang diberikan sektor perbankan syariah terhadap pertumbuhan ekonomi Provinsi Banten khususnya selama lima tahun terakhir, yaitu periode 2009 sampai 2013 ? 


\section{KERANGKA KONSEPTUAL}

Perkembangan ekonomi suatu wilayah lazim diketahui dengan melihat berapa besar output yang dihasilkan penduduk wilayah tersebut selama jangka waktu tertentu. Output tersebut tercermin dari deretan angka dalam Produk Domestik Bruto (PDB) untuk skala nasional, sedangkan untuk wilayah provinsi dan kabupaten/kota menggunakan Produk Domestik Regional Bruto (PDRB). Ada tiga metode dalam menghitung angka PDRB, yaitu metode produksi, pengeluaran, dan pendapatan. Nilai PDRB dalam penelitian ini menggunakan metode produksi.

PDRB dengan pendekatan produksi diperoleh melalui penjumlahan nilai tambah bruto (gross value added) dari semua sektor produksi. Perhitungan PDRB dengan pendekatan produksi di Indonesia dilakukan dengan menjumlahkan semua sektor industri yang ada, termasuk di dalamnya adalah sektor bank dan lembaga keuangan lainnya. Pada dasarnya sudah terlihat dengan jelas berapa kontribusi sektor perbankan dan lembaga keuangan lainnya terhadap PDRB. Namun karena masih bersifat umum, belum terukur dengan pasti berapa besarnya kontribusi perbankan syariah terhadap nilai PDRB Banten.

Untuk mengukur kinerja perbankan syariah sebagai lembaga intermediasi, bisa dengan cara melihat kemampuan bank tersebut dalam menghimpun dana pihak ketiga (DPK) dan menyalurkannya kembali ke masyarakat dalam bentuk pembiayaan. DPK bank syariah terdiri dari tabungan mudharabah, deposito mudharabah dengan berbagai termin, baik satu bulan; 3 bulan; 6 bulan; 12 bulan; dan lebih dari 12 bulan, serta giro wadiah. Sedangkan pembiayaan diberikan bisa dalam bentuk akad jual beli, bagi hasil, dan sewa.

Semakin banyak DPK yang berhasil dihimpun, diduga semakin memberi kontribusi positif terhadap pertumbuhan ekonomi Banten. Artinya, semakin banyak nasabah menyimpan dana di bank syariah, maka semakin banyak pula transaksi keuangan di bank syariah yang tercatat dalam PDRB.

Begitu juga halnya dengan pembiayaan, semakin banyak pembiayaan yang disalurkan, diduga semakin berpengaruh positif terhadap pertumbuhan ekonomi Banten. Karena pembiayaan merupakan salah satu sumber pendanaan untuk meningkatkan investasi dan menggerakan roda perekonomian. 
Penelitian ini sangat penting dilakukan sebagai bagian dari resiprocal research dari penelitian yang dilakukan penulis dua tahun yang lalu dengan mengangkat tema pengaruh variabel ekonomi makro terhadap rasio pembiayaan bermasalah (Non Performing Financing/ NPF) bank syariah di Banten. Hasil penelitian menunjukkan bahwa performa pembiayaan bank syariah yang dicerminkan dalam NPF sangat dipengaruhi perkembangan ekonomi daerah yang tercermin dalam PDRB Banten.

Dengan menggunakan perspektif yang berbeda, penulis menjadikan perkembangan ekonomi Banten sebagai variabel terikat/ dependent variable, dan pertumbuhan bank syariah sebagai variabel bebas/ independent variable. Yang dimaksud pertumbuhan bank syariah dilihat dari aspek pengumpulan DPK dan penyaluran pembiayaan.

\section{PERBANKAN SYARIAH DAN PERTUMBUHAN EKONOMI}

\section{A. Konsep Pertumbuhan Ekonomi}

Produktif atau tidaknya sebuah negara dapat dilihat dari kemampuan masyarakatnya dalam menghasilkan barang dan jasa. Kemampuan produksi tersebut dihitung dalam Produk Domestik Bruto (PDB). Bila nilai PDB dari tahun ke tahun mengalami kenaikan, maka ekonomi negara tersebut dikatakan sedang tumbuh dan masyarakatnya relatif produktif.

Alat yang tepat dalam mengukur pertumbuhan ekonomi yaitu PDB riil atau dikenal dengan PDB atas dasar harga konstan. Penggunaan harga konstan untuk menghilangkan pengaruh inflasi, sehingga angka PDB yang muncul merupakan nilai riil dari total output barang dan jasa. Dumairy mengungkapkan ada tiga metode mengubah PDB atas harga berlaku menjadi harga konstan (Dumairy, 1996). Pertama, yaitu metode revaluasi. Menurut metode ini, PDB konstan diperoleh dengan menetapkan tahun dasar (based year) yang merupakan tahun di mana perekonomian dalam kondisi stabil. Harga barang, yang diwakili oleh indeks harga konsumen (IHK), pada tahun tersebut digunakan sebagai harga konstan untuk tahun-tahun berikutnya.

Metode kedua adalah ekstrapolasi. Metode ini dilakukan dengan cara memperbarui (updating) nilai tahun dasar sesuai dengan indeks produksi atau tingkat pertumbuhan riil dari tahun sebelumnya. Metode ketiga adalah metode 
deflasi, dilakukan dengan cara membagi nilai masing-masing tahun dengan harga relatif yang sesuai (indeks harga x $1 / 100$ ).

\section{B. Faktor-Faktor Yang Mempengaruhi Pertumbuhan Ekonomi}

Ada beberapa faktor yang bisa memengaruhi pertumbuhan ekonomi suatu negara atau wilayah. Para ekonom Klasik mengelompokkannya ke dalam tujuh faktor sebagai berikut (Raharja, 2006):

Faktor pertama adalah ketersediaan barang modal. Agar ekonomi mengalami pertumbuhan, maka stok barang modal harus ditambah dengan cara peningkatan investasi. Salah satu upaya dalam meningkatkan investasi adalah dengan menangani faktor-faktor yang memengaruhi tingkat investasi, diantaranya stabilitas politik, pelayanan birokrasi dalam satu pintu, pajak yang rendah, dan lain sebagainya.

Kedua, kualitas tenaga kerja. Khusus di negara sedang berkembang, tenaga kerja (TK) masih merupakan faktor produksi yang sangat dominan. Penambahan tenaga kerja umumnya berpengaruh terhadap peningkatan output. Yang menjadi pertanyaan adalah berapa banyak penambahan TK akan terus meningkatkan output. Selama ada sinergi antara TK dan teknologi, penambahan TK akan memacu pertumbuhan ekonomi. Jumlah TK yang dapat dilibatkan dalam proses produksi akan semakin sedikit bila teknologi yang digunakan makin tinggi atau akan terjadi trade off.

Faktor ketiga yaitu perkembangan teknologi. Kemajuan teknologi makin memperbesar ketimpangan ekonomi antar bangsa, utamanya negara maju dengan negara sedang berkembang. Untuk mengatasi ketimpangan antara tenaga kerja dan teknologi, beberapa ekonom mengajukan konsep berupa teknologi tepat guna. Dengan penggunaan teknologi ini, manusia dapat memanfaatkan secara optimal apa yang ada dalam diri dan lingkungannya. Bahkan kelebihan penggunaan teknologi tepat guna adalah ditekannya pemborosan penggunaan SDA atau energi dalam proses produksi.

Faktor keempat adalah kemampuan finansial. Dalam perekonomian modern, uang memegang peran sentral. Makin banyak uang yang digunakan dalam proses produksi, makin besar output yang dihasilkan. Tetapi dengan jumlah uang yang sama, dapat dihasilkan output yang lebih besar jika penggunaannya efisien. Tingkat 108 
efisiensi penggunaan uang sangat ditentukan oleh tingkat efisiensi sistem perbankan. Pembenahan sistem keuangan ini akan memberi sumbangan yang signifikan terhadap pertumbuhan ekonomi.

Faktor kelima yang dapat mendorong pertumbuhan ekonomi yaitu kemampuan manajerial. Manajemen adalah peralatan yang sangat dibutuhkan untuk mengelola perekonomian modern, terutama perekonomian yang sangat mengandalkan mekanisme pasar. Sistem manajemen yang baik, terkadang jauh lebih berguna dibanding barang modal yang banyak, uang yang berlimpah dan teknologi tinggi. Banyak contoh di mana suatu negara yang tidak terlalu mengandalkan teknologi tinggi tapi mampu mempertahankan pertumbuhan ekonominya, misalnya Thailand. Dengan potensi pertanian dan keindahan alamnya, Thailand mampu mengelola agribisnis dan sektor pariwisata dengan baik. Bahkan dengan hasil pertaniannya, yaitu beras ketan, Thailand dapat membeli pesawat buatan Indonesia, dengan cara imbal jual (counter trade).

Faktor keenam adalah kemampuan wirausaha (entrepreneurship). Kewirausahaan diartikan sebagai kemampuan dan keberanian mengambil risiko untuk memperoleh keuntungan. Para wirausahawan atau pengusaha harus mempunyai perkiraan yang matang bahwa input yang dikombinasikannya akan menghasilkan barang dan jasa yang dibutuhkan oleh masyarakat, sehingga timbal baliknya akan memberikan keuntungan yang maksimal bagi perusahaan.

Faktor ketujuh yang tidak kalah pentingnya adalah penguasaan informasi. Syarat agar pasar berfungsi sebagai alokasi sumber daya ekonomi yang efisien adalah adanya informasi yang sempurna dan seimbang (perfect and simetric information). Kegagalan pasar merupakan akibat tidak terpenuhinya asumsi ini. Sebab semakin banyak, semakin benar dan semakin berimbang arus informasi, para pelaku ekonomi dapat mengambil keputusan dengan lebih cepat dan lebih baik, sehingga sumber daya ekonomi makin efisien. Dapat dikatakan bahwa penguasaan informasi sangat menunjang pertumbuhan ekonomi.

\section{Peran Sektor Perbankan Dalam MendorongPertumbuhan Ekonomi}

Pohan mengungkapkan terdapat empat jalur yang bisa digunakan untuk menganalisa peran sektor perbankan terhadap perkembangan ekonomi. Keempat 
jalur tersebut dinamakan efek substitusi, efek suku bunga, efek kekayaan, efek ekspektasi masyarakat (Pohan, 2008).

Efek substitusi terjadi karena hukum deminishing marginal utility, yang berlaku pada konsumsi barang dan jasa, berlaku juga pada penggunaan uang. Semakin banyak uang diterima oleh seseorang, semakin kecil nilai tambah kegunaan yang bisa diperoleh orang tersebut atas uang yang diterimanya. Makin banyak uang yang diterima seseorang, akan semakin besar hasrat orang tersebut menukarkan uangnya dengan barang atau jasa yang dapat memberi nilai tambah kegunaan yang lebih besar. Kondisi inilah yang disebut dengan efek substitusi.

Efek substitusi menjadi penghubung antara sektor moneter dengan sektor riil. Penambahan jumlah uang beredar di pasar akan meningkatkan konsumsi masyarakat terhadap barang dan jasa. Saat jumlah uang yang dipegang menjadi semakin banyak, masyarakat akan menukarkannya menjadi bentuk lain yang memberi nilai tambah, misalnya dengan membeli barang dan jasa, sehingga konsumsi barang dan jasa akan meningkat. Peningkatan permintaan akan mendorong peningkatan produksi, dan akhirnya sektor riil berjalan semakin cepat.

Peningkatan aktivitas di sektor riil akan meningkatkan pertumbuhan ekonomi dan memperluas kesempatan kerja. Namun, kenaikan produksi tidak akan berlangsung terus-menerus tanpa batas. Pada suatu saat akan mencapai titik jenuh. Bila kapasitas perekonomian mencapai titik jenuh dan kapital yang tersedia menjadi terbatas, perekonomian tidak mampu lagi meningkatkan produksi dan memperluas investasi. Dampak yang terjadi berikutnya bukan lagi kenaikan produksi melainkan kenaikan harga barang dan jasa, yang dikenal dengan inflasi.

Kondisi inilah yang diyakini oleh Milton Friedman bahwa ekspansi moneter dalam jangka panjang tidak akan mendorong pertumbuhan ekonomi dan memperluas kesempatan kerja, tetapi hanya akan meningkatkan inflasi.

Efek suku bunga muncul karena memengaruhi masyarakat dalam memilih bentuk kekayaan yang ingin dimilikinya, apakah dalam bentuk uang, financial assets, atau benda-benda riil seperti tanah, rumah, emas dan lan sebagainya. Mana yang memberi hasil lebih tinggi akan lebih diminati.

Ekspansi moneter selain mendorong masyarakat menukarkan uangnya dengan barang dan jasa dapat juga mendorong masyarakat menukarkan uangnya ke dalam 
bentuk aset keuangan (financial asset). Preferensi masyarakat untuk membeli aset keuangan mengakibatkan kenaikan harga-harga aset keuangan tersebut yang berarti pula terjadinya penurunan suku bunga dari aset keuangan tersebut. Penurunan suku bunga akan mengurangi biaya modal (cost of capital) dan pada gilirannya akan mendorong kegiatan produksi dan investasi sehingga meningkatkan pertumbuhan ekonomi serta memperluas kesempatan kerja.

Di sisi lain, penurunan suku bunga dapat mendorong perpindahan kapital ke luar negeri atau capital flight, khususnya ke negara di mana tingkat bunganya lebih menguntungkan. Capital flight pada gilirannya akan merugikan neraca pembayaran.

Neraca pembayaran dapat mewakili rapor suatu negara. Neraca pembayaran diterjemahkan sebagai suatu catatan sistematis mengenai transaksi ekonomi yang dilakukan penduduk (residen) suatu negara dengan penduduk negara lain (nonresiden) dalam jangka waktu tertentu. Dengan demikian, dalam neraca pembayaran akan tergambar besarnya ekspor, impor, jasa-jasa, dan lalu lintas dari dan ke suatu negara. Dengan melihat neraca pembayaran selintas bisa diketahui kinerja ekonomi eksternal suatu negara.

Kenaikan harga barang atau inflasi, bagi sebagian masyarakat yang memiliki kekayaan dalam bentuk riil seperti tanah, bangunan, emas, dan lain-lain, akan menyebabkan meningkatnya nominal kekayaan yang mereka miliki. Misalnya, tanah yang semula harganya Rp 100 juta, dengan naiknya harga-harga, nilai tanah tersebut meningkat menjadi Rp 120 juta. Secara nominal, kekayaan pemilik tanah mengalami peningkatan.

Kenaikan kekayaan nominal ini akan membuat masyarakat merasa dirinya lebih kaya dibandingkan dengan sebelum adanya inflasi. Perasaan tersebut akan mendorong masyarakat untuk meningkatkan konsumsinya. Dalam teori moneter, kondisi di atas dikenal dengan wealth effect atau efek kekayaan yang dampak moneternya sama dengan efek substitusi dan efek suku bunga.

Ekspektasi masyarakat terhadap kenaikan harga pada gilirannya akan mendorong kenaikan suku bunga. Apabila suku bunga meningkat lebih kecil dibandingkan dengan kenaikan harga, secara riil return atas aset keuangan yang dimiliki akan menurun. Penurunan tersebut akan mendorong orang mengalihkan kekayaannnya dari bentuk aset keuangan ke bentuk aset riil. 
Dengan kondisi demikian, apabila masyarakat atau perusahaan dapat memanfaatkan berbagai informasi atau data moneter dengan baik sehingga dapat memperkirakan inflasi, mereka akan menaikkan harga barang yang diproduksinya. Di sisi lain, para pekerja juga akan meminta upah yang lebih tinggi mendahului kemungkinan inflasi yang mereka perkirakan akan terjadi.

Apabila tindakan antisipasi itu dilakukan oleh sebagian besar masyarakat, tindakan tersebut akan membawa dua implikasi moneter yang sangat penting, yaitu pertama, kebijakan moneter menjadi tidak efektif. Karena kebijakan moneter tidak mengubah sektor riil, yaitu konsumsi, produksi, investasi, dan kesempatan kerja. Hal yang terjadi hanyalah perubahan harga. Kedua, ekspektasi masyarakat terhadap inflasi akan mengakibatkan inflasi yang semula hanya merupakan dugaan, justru menjadi kenyataan.

Keempat jalur atau efek inilah yang menjadi hubungan sebab akibat antara kebijakan moneter dengan perekonomian secara makro. Relasi yang demikian kompleks ini pula harus menjadi pertimbangan bagi pengambil kebijakan moneter untuk menentukan apa target kebijakan moneter yang akan dituju dan bagaimana strategi pencapaiannya.

\section{Penelitian Terdahulu}

\section{Analisis Prospek Kontribusi Ekonomi Syariah di Indonesia}

Wahyono dalam sebuah penelitiannya menyampaikan hasil kajian kualitatif tentang kontribusi kontribusi ekonomi syariah dalam meningkatkan kesejahteraan masyarakat Indonesia. Fokus analisa ditekankan pada faktor penduduk, sumber daya manusia (SDM), dan faktor kontribusi pemerintah (Wahyono, TT).

Hasil analisanya menyatakan bahwa dari aspek demografi atau kependudukan, Indonesia merupakan negara dengan penduduk Islam terbesar di dunia. Jumlah penduduk muslim di Indonesia pada tahun 2010 sekitar 85\% dari 240.271 .522 penduduk. Kondisi ini tentu menjadi faktor kuat untuk mendukung perkembangan dan kontribusi ekonomi syariah di Indonesia. Pertumbuhan lembaga keuangan syariah yang pesat di Indonesia, mengindikasikan peningkatan kesadaran penduduk Indonesia akan syariat Islam dan berdampak pada peningkatan permintaan jasa layanan lembaga keuangan berbasis syariah. 
Dari sisi pengembangan SDI, ternyata SDI yang berkecimpung di lembaga keuangan syariah belum sepenuhnya memiliki kapasitas yang ideal. Realitasnya, SDI merupakan sumber daya manusia pada lembaga keuangan konvensional yang kemudian sedikit dipoles dengan label syariah. Tak mengherankan jika kemudian berbagai kritik bermunculan terhadap praktik ekonomi syariah di Indonesia, yang dinilai tidak jauh berbeda dengan praktek serupa di lembaga keuangan konvensional.

Jika melihat dari keterlibatan pemerintah, Wahyono mengungkapkan beberapa upaya yang telah dilakukan oleh pemerintah kaitannya dengan pengembangan ekonomi syariah di Indonesia. Diantaranya penerbitan UU No 19 Tahun 2008 Tentang Surat Berharga Syariah Nasional dan UU PS. Keberadaan UU No 19/2008 merupakan upaya pemerintah meningkatkan porsi pembiayaan pembangunan nasional melalui skema pembiayaan syariah dari obligasi negara dan surat berharga lainnya yang memang memiliki peluang besar bagi Indonesia untuk memperolehnya dari investor Timur Tengah maupun umat Islam Indonesia sendiri. Adapun UU PS yang secara khusus membahas perbankan syariah merupakan upaya pemerintah dalam menguatkan kontribusi lembaga keuangan syariah dalam memperkokoh pembangunan nasional.

Selain itu, pemerintah juga sudah mulai memperhatikan zakat untuk mengurangi kemiskinan di Indonesia. Salah satu rekomendasi Konferensi Dewan Zakat Asia Tenggara (DZAT) ke 2 yang berlangsung di Padang yaitu mendesak dibentuknya kementerian zakat. Rekomendasi tersebut disambut DPR dengan mendesak dibentuknya DITJEN zakat. Selain itu, Presiden pun juga mengungkapkan bahwa zakat bisa digunakan untuk memenuhi kebutuhan konsumtif yang pada akhirnya akan mengurangi kemiskinan dan meningkatkan kesejahteraan masyarakat.

\section{Peranan Ekonomi Syariah dalam Pembangunan Daerah}

Dengan menggunakan pendekatan analisis deskriptif, Rusydiana dan Syafi'i menjelaskan ada beberapa indikator yang dapat menjadi tolok ukur bagi kontribusi sektor keuangan syariah terhadap perekonomian daerah. Indikator pertama yaitu semakin banyaknya bank-bank syariah nasional yang membuka cabang di daerahdaerah. Pembukaan kantor cabang ini tentu membawa implikasi bagi pembangunan ekonomi setempat karena adanya aktivitas intermediasi yang dilakukan perbankan 
syariah yaitu menyalurkan dana dari pihak yang surplus ke pada pihak yang shortage. (Rusdiana dan Syafi'i, TT).

Kehadiran perbankan syariah sampai di daerah mampu menjadi solusi atas 'kebiasaan' bank konvensional yang selalu menginvestasikan dana desentralisasi milik pemda ke instrumen SBI. Oleh karena itu, kehadiran UUS dari Bank Pembangunan Daerah (BPD) menjadi pilihan alternatif bagi pemda untuk mengalokasikan dana desentralisasi ke sektor-sektor produktif dengan tetap memperoleh imbal hasil yang kompetitif.

Indikator kedua, tidak kalah pentingnya adalah peran yang dimainkan oleh lembaga-lembaga keuangan mikro dan kecil syariah seperti BMT, Koperasi Syariah, dan BPRS yang mampu menjangkau masyarakat sampai lingkup terkecil yang tidak mampu dijangkau oleh bank-bank umum. Sudah banyak peran yang dimainkan oleh lembaga keuangan mikro syariah ini dan sudah banyak pula pengaruhnya bagi perbaikan ekonomi daerah. Para officer lembaga keuangan mikro syariah rajin melakukan sosialisasi ekonomi syariah kepada masyarakat, sehingga masyarakat menjadi entreprenur yang berjuang mengangkat taraf hidupnya ke arah yang lebih baik.

\section{Analisis Kontribusi Perbankan Syariah Terhadap Pertumbuhan Ekonomi Indonesia}

Rama mencoba melakukan identifikasi masalah apakah perbankan syariah berpengaruh terhadap pertumbuhan ekonomi nasional (ia menyebutnya finance-led growth hypothesis)?, dan ataukah justru pertumbuhan ekonomi nasional yang berpengaruh terhadap perkembangan sektor perbankan syariah (growth-led finance hypothesis)? Alat analisis yang digunakan dalam penelitian kausalitas ini dengan cara Uji Kausalitas Granger (Granger Causality) berdasarkan Error Correction Model (Ali Rama).

Hasil uji kausalitas Granger menunjukkan pola hubungan finance-led growth. Artinya, perbankan syariah yang direpresentasikan melalui total pembiayaan dan DPK secara positif dan signifikan berhubungan dengan pertumbuhan ekonomi dan riil output di Indonesia dalam jangka panjang. Penelitian ini juga mengindikasikan bahwa peningkatan infrastruktur perbankan syariah di Indonesia akan memberikan 
manfaat terhadap perkembangan ekonomi dan hal ini penting dalam jangka panjang untuk perkembangan kesejahteraan masyarakat.

Dalam rekomendasinya, Rama mengungkapkan pentingnya untuk meningkatkan infrastruktur keuangan seperti peningkatan kuantitas dan kualitas sumber daya manusia untuk memenuhi permintaan industri keuangan syariah yang diprediksi akan mengalami pertumbuhan yang cukup pesat di masa mendatang.

Diperlukan juga perangkat hukum yang memadai sebagai bentuk regulatory framework bagi pelaku-pelaku industri keuangan syariah. Sistem manajemen risiko juga menjadi hal penting untuk mendukung perkembangan indsutri ini dalam jangka panjang.

\section{Kontribusi Perkembangan Perbankan Syariah Terhadap Tingkat Pertumbuhan Ekonomi dan Kemiskinan di Indonesia}

Ilyas mencoba memecahkan masalah mengenai kontribusi perbankan syariah terhadap pertumbuhan ekonomi dan kemiskinan di Indonesia. Variabel perbankan syariah diwakili oleh financing to deposit ratio (FDR). Sedangkan pertumbuhan ekonomi diwakili oleh angka Product Domestic Brutto (PDB), (Iyas, 2011).

Metodologi penelitian yang digunakan adalah library research, yaitu dilaksanakan dengan menggunakan literatur (kepustakaan) dari penelitian sebelumnya, dengan bantuan kelengkapan data yang dikutip dari Bank Indonesia dan Badan Pusat Statistik.

Hasil penelitian membuktikan bahwa kontribusi perbankan syariah terhadap tingkat pertumbuhan ekonomi sebesar 31,3\% dan terhadap kemiskinan sebesar 15,5\%. Artinya kontribusi yang diberikan perbankan syariah terhadap pembangunan ekonomi dan pengentasan kemiskinan belum sesuai dengan tujuan-tujuan perbankan syariah itu sendiri, maka perlu ada kebijakan yang lebih arif lagi dalam mengelola dana masyarakat agar sesuai dengan amanah dan tujuan tersebut. Ketika pertumbuhan ekonomi berjalan benar akan berimbas pada penurunan angka kemiskinan baik secara langsung maupun secara tidak langsung. 


\section{Kinerja Keuangan Perbankan Syariah di Indonesia dan Kontribusinya Bagi Pembangunan Nasional}

Penelitian ini berupaya untuk mengukur kinerja keuangan perbankan syariah di Indonesia dan dikaitkan dengan kontribusinya terhadap pembangunan nasional selama periode 2005 sampai 2009. Andriansyah mencoba melakukan analisa deskriptif kuantitatif terhadap data laporan keuangan perbankan syariah dalam statistik perbankan syariah yang dirilis oleh BI. (Ardiansyah).

Salah satu hasil analisanya menggambarkan bahwa selama periode 2005 sampai 2009 kontribusi perbankan syariah terhadap pembangunan nasional masih relatif kecil. Hasil ini dibuktikan dengan dominannya kontribusi yang disalurkan bank syariah pada sektor jasa yang mencapai nilai rata-rata 29,71 persen. Sebaliknya, kontribusi pada sektor primer seperti pertanian dan perkebunan relatif kecil hanya sekitar 3,2 persen selama periode yang sama. Rendahnya pembiayaan syariah pada primer menandakan masih lemahnya komitmen perbankan syariah pada sektor yang menjadi tulang punggung bagi sebagian besar rakyat Indonesia.

Kontribusi perbankan syariah terhadap pembangunan nasional juga dapat dilihat dari rasio-rasio keuangan bank umum syariah dan unit usaha syariah. Dari beberapa rasio yang ada, FDR atau rasio pembiayaan terhadap dana pihak ketiga pada perbankan syariah selama lima tahun terakhir berada pada rata-rata 99,63\% yang menunjukkan bahwa perbankan syariah aktif menyalurkan dana kepada masyarakat.

Andriansyah menyimpulkan bahwa perbankan syariah telah menunjukkan kinerja keuangan yang menggembirakan meskipun perannya masih perlu untuk terus dikembangkan. Perbankan syariah juga telah memberikan kontribusi penting bagi pembangunan nasional dengan melaksanakan fungsi intermediasi keuangan. Peran lain yang kini dituntut dari perbankan syariah adalah partisipasi aktifnya dalam pembiayaan pada sektor primer di Indonesia dan mempraktekkan prinsip syariah terutama prinsip bagi hasil dalam operasionalnya. 


\section{Hipotesis Penelitian}

Secara lengkap hipotesis yang akan diuji adalah sebagai berikut:

$H_{o}: \beta_{1}, \beta_{2}=0$; Diduga variabel DPK dan pembiayaan perbankan syariah, secara parsial maupun simultan, tidak berkorelasi positif terhadap peningkatan PDRB Banten.

$H_{a}: \beta_{1}, \beta_{2}>0$; Diduga variabel DPK dan pembiayaan perbankan syariah, secara parsial maupun simultan, berkorelasi positif terhadap peningkatan PDRB Banten.

\section{METODE}

\section{A. Objek Penelitian}

Penelitian ini coba mengambil objek perkembangan ekonomi Banten yang dikutip dari sumber resmi berupa laporan perkembangan ekonomi Banten, disandingkan dengan perkembangan perkembangan perbankan syariah di Banten yang diambil dari statistik perkembangan perbankan syariah di Provinsi Banten.

Perkembangan ekonomi Banten selalu menarik untuk dijadikan objek penelitian disebabkan karena posisi geografisnya dan aspek demografisnya. Posisi Banten secara geografis bertetangga dengan ibukota negara DKI Jakarta. Jarak yang relatif dekat dengan ibukota negara menjadi kelebihan tersendiri bagi Banten karena diharapkan mendapat manfaat dari potongan kue pembangunan yang terjadi di DKI Jakarta, baik dari sisi peningkatan PDRB maupun semakin bertambahnya jaringan perbankan syariah. Dari sisi demografi, ciri kultur agamis masyarakat Banten yang Islami menjadi daya tarik tersendiri untuk diteliti. Dengan mengukur kontribusi perbankan syariah bagi perekonomian Banten, secara tidak langsung riset ini juga bisa mengetahui kontribusi umat muslim Banten terhadap kemajuan ekonomi daerahnya.

\section{B. Teknik Pengumpulan Data}

Penelitian dilakukan dengan mengumpulkan data sekunder yang dipublikasikan oleh lembaga terkait, baik melalui situs resmi atau melalui katalog yang diterbitkan lembaga tersebut yang tersebar di perpustakaan daerah atau Badan Pusat Statistik (BPS) Provinsi Banten. Rentang waktu selama lima tahun terakhir, yaitu tahun 2009 
sampai 2013. Data yang diperlukan terdiri dari jumlah DPK dan jumlah pembiayaan bank syariah di Banten, serta PDRB Banten atas dasar harga konstan.

\section{Alat Analisis}

Salah satu alat analisis yang tepat untuk mengukur kontribusi sektor perbankan terhadap perekonomian Banten yaitu regresi berganda dengan metode ordinary least square (OLS). Adapun model regresi yang ditawarkan penulis adalah sebagai berikut:

$$
\operatorname{PDRB}=\alpha+\beta_{1} \mathrm{DPK}+\beta_{2} \text { Pemby }+\varepsilon
$$

Dimana:

$$
\begin{array}{ll}
\text { PDRB } & =\text { Produk Domestik Regional Bruto (Rp. Miliar) } \\
\alpha & =\text { Konstanta } \\
\beta_{1}, \beta_{2} & =\text { Koefisien Regresi } \\
\text { DPK } & =\text { Jumlah Dana Pihak Ketiga (Rp. Miliar) } \\
\text { Pemby } & =\text { Jumlah Pembiayaan yang disalurkan (Rp. Miliar) } \\
\varepsilon & =\text { Standard error }
\end{array}
$$

Data sekunder yang telah dikumpulkan kemudian diolah dengan alat bantu ekonometrik berupa software Eviews. Langkah selanjutnya adalah melakukan serangkaian pengujian, baik uji statistik maupun uji hipotesis.

Uji statistik dilakukan untuk mengetahui apakah data yang digunakan layak atau tidak untuk dijadikan sebuuah model regresi. Sedangkan uji hipotesis dilakukan untuk memastikan adanya pengaruh antara variabel bebas (DPK dan Pembiayaan) dan variabel terikat (PDRB).

\section{KONTRIBUSI PERBANKAN SYARIAH TERHADAP PEREKONOMIAN BANTEN}

Kemajuan yang terjadi di sektor perbankan syariah dapat memberi pengaruh positif bagi pertumbuhan ekonomi regional, khususnya di Banten. Semakin banyak masyarakat Banten yang memanfaatkan jasa perbankan syariah, akan semakin mendorong pertumbuhan ekonomi Banten.

Potret perkembangan sektor perbankan syariah dan perkembangan ekonomi Banten dalam bentuk PDRB tersaji dalam tabel 1 berikut ini. 
Tabel 1. Rekapitulasi Sampel Penelitian Tahun 2009-2013

\begin{tabular}{|c|c|c|c|c|}
\hline Tahun & Bulan & $\begin{array}{c}\text { PDRB } \\
\text { (Rp.Miliar) }\end{array}$ & $\begin{array}{c}\text { DPK } \\
\text { (Rp.Miliar) }\end{array}$ & $\begin{array}{c}\text { Pembiayaan } \\
\text { (Rp.Miliar) }\end{array}$ \\
\hline \multirow{12}{*}{2009} & Januari & 17318 & 831 & 832 \\
\hline & Februari & 17318 & 837 & 842 \\
\hline & Maret & 17318 & 823 & 851 \\
\hline & April & 17787 & 837 & 849 \\
\hline & Mei & 17787 & 867 & 877 \\
\hline & Juni & 17787 & 894 & 896 \\
\hline & Juli & 21310 & 1025 & 919 \\
\hline & Agustus & 21310 & 1102 & 953 \\
\hline & September & 21310 & 1347 & 990 \\
\hline & Oktober & 21454 & 1475 & 1035 \\
\hline & November & 21454 & 1380 & 1073 \\
\hline & Desember & 21454 & 1498 & 1111 \\
\hline \multirow{12}{*}{2010} & Januari & 21166 & 1690 & 1135 \\
\hline & Februari & 21166 & 1699 & 1205 \\
\hline & Maret & 21166 & 1726 & 1244 \\
\hline & April & 21820 & 1817 & 1289 \\
\hline & Mei & 21820 & 2084 & 1507 \\
\hline & Juni & 21820 & 2351 & 1621 \\
\hline & Juli & 22601 & 2596 & 1687 \\
\hline & Agustus & 22601 & 2637 & 1786 \\
\hline & September & 22601 & 2818 & 1827 \\
\hline & Oktober & 22807 & 2742 & 1868 \\
\hline & November & 22807 & 2624 & 1969 \\
\hline & Desember & 22807 & 3007 & 2086 \\
\hline \multirow{3}{*}{2011} & Januari & 22598 & 2750 & 2207 \\
\hline & Februari & 22598 & 2674 & 2321 \\
\hline & Maret & 22598 & 3406 & 2440 \\
\hline
\end{tabular}


Jurnal Islamiconomic Vol.6 No.1 Januari - Juni 2015

\begin{tabular}{|c|c|c|c|c|}
\hline Tahun & Bulan & $\begin{array}{c}\text { PDRB } \\
\text { (Rp.Miliar) }\end{array}$ & $\begin{array}{c}\text { DPK } \\
\text { (Rp.Miliar) }\end{array}$ & $\begin{array}{c}\text { Pembiayaan } \\
\text { (Rp.Miliar) }\end{array}$ \\
\hline & April & 23188 & 2974 & 2918 \\
\hline & Mei & 23188 & 3228 & 3294 \\
\hline & Juni & 23188 & 2856 & 2750 \\
\hline & Juli & 24711 & 2965 & 2804 \\
\hline & Agustus & 24711 & 3113 & 3074 \\
\hline & September & 24711 & 3324 & 3245 \\
\hline & Oktober & 25974 & 3464 & 3487 \\
\hline & November & 25974 & 3722 & 3571 \\
\hline & Desember & 25974 & 4680 & 3707 \\
\hline \multirow{12}{*}{2012} & Januari & 24017 & 4510 & 3720 \\
\hline & Februari & 24017 & 4362 & 3711 \\
\hline & Maret & 24017 & 4535 & 3772 \\
\hline & April & 24702 & 4846 & 3836 \\
\hline & Mei & 24702 & 4656 & 3884 \\
\hline & Juni & 24702 & 4944 & 4001 \\
\hline & Juli & 26176 & 5134 & 2965 \\
\hline & Agustus & 26176 & 5084 & 4048 \\
\hline & September & 26176 & 5181 & 4096 \\
\hline & Oktober & 27499 & 5283 & 4231 \\
\hline & November & 27499 & 5635 & 4410 \\
\hline & Desember & 27499 & 5537 & 4698 \\
\hline \multirow{8}{*}{2013} & Januari & 25451 & 5318 & 4765 \\
\hline & Februari & 25451 & 5649 & 4908 \\
\hline & Maret & 25451 & 5651 & 5031 \\
\hline & April & 26152 & 5399 & 5088 \\
\hline & Mei & 26152 & 5450 & 5091 \\
\hline & Juni & 26152 & 5321 & 5449 \\
\hline & Juli & 27668 & 5323 & 5261 \\
\hline & Agustus & 27668 & 5638 & 5360 \\
\hline
\end{tabular}




\begin{tabular}{|l|l|r|r|r|}
\hline \multirow{2}{*}{ Tahun } & Bulan & $\begin{array}{c}\text { PDRB } \\
\text { (Rp.Miliar) }\end{array}$ & $\begin{array}{c}\text { DPK } \\
\text { (Rp.Miliar) }\end{array}$ & $\begin{array}{c}\text { Pembiayaan } \\
\text { (Rp.Miliar) }\end{array}$ \\
\hline \multirow{7}{*}{} & September & 27668 & 5643 & 5447 \\
\cline { 2 - 5 } & Oktober & 29105 & 5660 & 5515 \\
\cline { 2 - 5 } & November & 29105 & 5381 & 5613 \\
\cline { 2 - 5 } & Desember & 29105 & 5483 & 5803 \\
\hline
\end{tabular}

Jika melihat angka PDRB Banten selama lima tahun terakhir menunjukkan kondisi yang menggembirakan dengan angka rata-rata per lima tahun mencapai lebih dari $\mathrm{Rp}$ 23,67 triliun. Nilai tersebut disumbangkan oleh nilai rata-rata tahunan tertinggi di tahun 2013 yang mencapai lebih dari Rp 27 triliun. Sektor yang konsisten menjadi penyumbang terbesar bagi PDRB setiap tahunnya adalah konsumsi rumah tangga dan belanja pemerintah (KER Banten, 2013).

Jika diperhatikan secara seksama, terjadi siklus yang selalu berulang, dimana saat PDRB meninggi di akhir tahun akan diikuti dengan penurunan di awal tahun berikutnya. Fenomena ini terjadi disebabkan sistem pencairan anggaran, baik nasional atau regional, baru dimulai di bulan April. Kemudian, agar penyerapan anggaran berjalan maksimal, maka terjadi 'kejar tayang' penyerapan anggaran di akhir tahun. Maka tidak heran bila triwulan I setiap tahun selalu menunjukkan PDRB yang lebih rendah dibanding triwulan IV tahun sebelumnya.

Dari sisi kemampuan perbankan syariah dalam mengumpulkan dana masyarakat juga patut diapresiasi. Selama lima tahun periode pengamatan, rata-rata DPK yang ditarik dari masyarakat mencapai lebih dari Rp 3,4 triliun. Rata-rata tertinggi disumbang pada tahun 2013 mencapai Rp 5,5 triliun.

Jika dilihat lebih jauh, pengumpulan DPK terendah terjadi pada bulan Maret 2009. Kondisi yang sama juga dialami oleh bank konvensional secara nasional, karena pada triwulan I 2009 bertepatan dengan hajat nasional pemilu 2009, baik pemilihan legislatif maupun pemilihan pilpres. Situasi ini mendorong masyarakat lebih memilih memegang cash money dibanding memanfaatkan jasa perbankan.

Sebaliknya, angka DPK maksimum yang bisa dikumpulkan perbankan syariah di Banten terjadi di bulan Oktober 2013 mencapai angkat lebih dari Rp 5,7 triliun. 
Kondisi ini terjadi seiring membaiknya pertumbuhan ekonomi Banten dimana pada saat yang sama angka PDRB tumbuh menjadi Rp 29 triliun.

Kemampuan bank syariah di Banten dalam mengumpulkan DPK diiringi dengan peningkatan kemampuannya dalam menyalurkan pembiayaan. Selama lima tahun periode pengamatan, rata-rata pembiayaan yang diberikan mencapai lebih dari Rp 2,9 triliun, dengan sumbangan rata-rata tertinggi terjadi di tahun 2013 mencapai lebih dari Rp 5,3 triliun. Dengan kata lain, di tahun 2013 tersebut hampir semua DPK yang dikumpulkan disalurkan kembali ke masyarakat sehingga financing to deposit ratio (FDR) lebih tinggi dibanding LDR bank konvensional.

Untuk nilai pembiayaan terendah terjadi di bulan Januari 2009 yang hanya mencapai Rp 832 miliar. Kondisi ini terjadi karena jaringan bank syariah di Banten masih sangat minim. Walaupun daya dukung masih minim, nilai FDR pada periode yang sama menunjukkan angka lebih dari 100\% karena DPK pada bulan Januari 2009 hanya sebesar Rp 831 miliar.

Nilai pembiayaan tertinggi dicapai pada bulan Desember 2013 mencapai Rp 5,8 triliun. Di saat yang sama angka DPK yang diperoleh sebesar Rp 5,5 triliun. Perbandingan ini menghasilkan angka FDR mencapai 106\%. Hasil ini menegaskan peran perbankan syariah di tahun 2013 memberikan dampak positif bagi perekonomian Banten sehingga pada periode yang sama pun PDRB Banten ikut tumbuh menjadi Rp 29 triliun, tumbuh 5,84\% year on year (yoy).

Data yang ditampilkan pada tabel 1 kemudian diolah melalui software Eviews untuk menghasilkan model ekonometrik yang kelak digunakan untuk memprediksi kontribusi perbankan syariah terhadap pertumbuhan ekonomi Banten. Model ekonometri yang dimaksud adalah sebagai berikut:

$$
\begin{array}{lll}
\text { PDRB }=35.297 & -0.037 * \mathrm{DPK}+0.036 * \text { Pembiayaan } \\
\mathrm{SE} & (0.240517) & (0.252787) \\
\mathrm{t}_{\text {hitung }} & (-0.155622) & (0.143244) \\
\mathrm{F}_{\text {hitung }}=15,46 & \\
\mathrm{R}^{2}=52,9 \% &
\end{array}
$$


Nilai konstanta 35,297 menunjukkan bahwa apabila fungsi intermediasi perbankan syariah tidak berjalan dengan baik, maka perekonomian Banten tetap tumbuh dengan nilai PDRB mencapai lebih dari Rp 35 triliun. Keadaan ini wajar terjadi karena operasional perbankan syariah di Banten relatif masih baru, sekitar satu dasawarsa, dibandingkan dengan kapitalisasi perbankan konvensional yang sudah puluhan tahun eksis di wilayah Banten.

Agar model regresi dapat diinterpretasikan dengan baik, maka perlu mempertimbangkan nilai Goodness of Fit $\left(\mathrm{R}^{2}\right)$. Nilai $\mathrm{R}^{2}$ yang diperoleh adalah sebesar 0,529, artinya kurang lebih 53\% peningkatan ekonomi Banten dipengaruhi oleh pertumbuhan sektor keuangan, termasuk di dalamnya ada perbankan syariah. Sisanya sekitar $47 \%$ dipengaruhi oleh faktor-faktor lain yang tidak tercakup dalam penelitian ini. Oleh karena nilai $\mathrm{R}^{2}$ yang diperoleh lebih dari 50\% maka model ekonometri yang dihasilkan sudah cukup representatif untuk digunakan sebagai prediktor.

Dengan $t_{\text {tabel }}$ sebesar 1,671 dan dibandingkan dengan thitung masing-masing variabel pembiayaan menghasilkan kesimpulan menerima Ho. Dengan kata lain, DPK dan pembiayaan bank syariah tidak bisa dianalisa secara parsial karena hasil uji $t$ menunjukkan DPK dan pembiayaan tidak berpengaruh secara parsial terhadap peningkatan PDRB Banten. Sedangkan pada uji $F$ diperoleh $F_{\text {tabel }}$ sebesar 15,46.

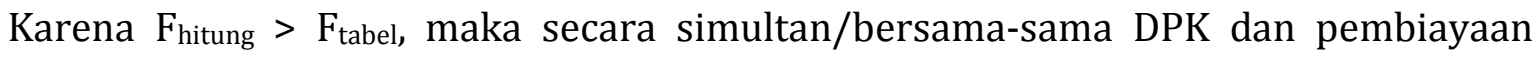
berpengaruh terhadap PDRB Banten.

Hasil uji F menegaskan bahwa fungsi intermediasi perbankan syariah berjalan dengan baik. Ketika DPK telah terkumpul, segera disalurkan oleh bank syariah dalam bentuk pembiayaan untuk menggerakan roda perekonomian Banten. Muaranya, gerak roda perekonomian yang didorong oleh pembiayaan bank syariah akan meningkatkan PDRB Banten. Meningkatnya PDRB berarti pula semakin bertambahnya pendapatan masyarakat Banten, dimana salah satunya dialokasikan dalam bentuk simpanan di lembaga keuangan syariah.

Hasil dari analisa regresi di atas menjadi komplementer dari penelitian deskriptif yang dilakukan oleh Rusydiana dan Antonio Syafii. Mereka mendeskripsikan bahwa keberadaan bank syariah di daerah membawa implikasi bagi pembangunan ekonomi setempat karena adanya aktivitas intermediasi yang 
dilakukan perbankan syariah yang menyalurkan dana dari pihak yang surplus ke pada pihak yang shortage.

Riset ini juga memperkuat hasil yang diperoleh Andriansyah. Ia melakukan analisa pada laporan keuangan perbankan syariah selama periode 2005 sampai 2009 yang menyimpulkan bahwa melalui nilai rata-rata FDR (financing to deposit ratio) yang mencapai 99,63\%, menggambarkan perbankan syariah menjalankan fungsi intermediasi dengan baik. Hanya saja garapan pembiayaannya belum menyentuh pada sektor primer, misalnya pertanian dan perkebunan.

Jika melihat kembali nilai kontribusi secara khusus perbankan syariah dan secara umum sektor keuangan yang mencapai 53\% terhadap PDRB Banten, menunjukkan pembangunan ekonomi Banten selama lima tahun terakhir didominasi oleh transaksi di sektor jasa keuangan. Hasil ini memperkuat riset yang telah dilakukan Chowdhury dan kawan-kawan, walaupun dengan cakupan yang berbeda (Abduh, 2012). Selama periode pengamatan 2004 sampai 2011, ekonomi Bangladesh didominasi oleh transaksi di sektor keuangan, dimana di dalamnya terdapat perbankan syariah. Seperti halnya Indonesia, di Bangladesh pun menganut dual banking system. Pembiayaan yang disalurkan oleh perbankan syariah berkontribusi terhadap pertumbuhan ekonomi Bangladesh dalam jangka panjang. Dalam salah satu rekomendasinya, Chowdhury mengharapkan peran pemerintah Bangladesh untuk mengembangkan sektor perbankan syariah yang telah menunjukkan kinerja yang baik agar lebih berkembang lagi dan menjadi salah satu pilar penting dalam pembangunan Bangladesh.

Dengan lingkup yang sedikit berbeda juga, riset yang dilakukan penulis ikut memperkuat riset lain yang dilakukan oleh Rama. Dengan pendekatan kausalitas granger, Rama menyimpulkan bahwa perbankan syariah yang direpresentasikan melalui total pembiayaan dan DPK secara positif dan signifikan berhubungan dengan pertumbuhan ekonomi dan riil output di Indonesia dalam jangka panjang. Ia juga menyimpulkan bahwa peningkatan infrastruktur perbankan syariah di Indonesia akan memberikan manfaat terhadap perkembangan ekonomi dan kesejahteraan masyarakat dalam jangka panjang.

Jika riset ini menunjukkan 53\% pertumbuhan PDRB disumbangkan oleh perbankan syariah, maka hasil ini sejalan dengan riset Ilyas yang menyatakan bahwa 
keberadaan perbankan syariah mampu memberikan kontribusi terhadap pertumbuhan ekonomi secara nasional sebesar $31,3 \%$.

\section{KESIMPULAN}

Jika melihat data pelaporan perbankan syariah di Provinsi Banten, dapat disimpulkan bahwa perbankan syariah menunjukkan perkembangan yang pesat dengan tingkat kepercayaan masyarakat yang tinggi sebagaimana ditandai penghimpunan dana pihak ketiga yang mencapai Rp 5,48 triliun pada akhir 2013. Selain itu, share asset perbankan syariah terhadap total asset perbankan tercatat 5,88 persen, meningkat dibandingkan dari posisi akhir tahun 2012 yang tercatat 5,71 persen.

Komitmen perbankan syariah dalam mendorong kegiatan ekonomi di Provinsi Banten terbukti dari penyaluran pembiayaan oleh perbankan syariah yang tumbuh 23,40 persen sehingga tercatat sebesar Rp 5,80 triliun pada akhir 2013. Rasio pembiayaan terhadap simpanan atau FDR juga menunjukkan peningkatan yang signifikan. Jika pada akhir tahun 2012 FDR tercatat 84,85 persen maka setahun kemudian pada akhir 2013 FDR tercatat 105,83 persen.

Sementara itu, pembiayaan bermasalah atau Non Performing Financing (NPF) di Provinsi Banten juga masih jauh di bawah ambang batas yang ditetapkan oleh BI. Sampai akhir 2013, NPF tercatat 1,53 persen.

Dari kacamata pengujian statistik, kontribusi perbankan syariah dapat diukur dengan menggunakan alat koefisien determinasi $\left(\mathrm{R}^{2}\right)$ yang menunjukkan angka 53 persen. Artinya, selama lima tahun pengamatan, dari 2009 sampai dengan 2013, perbankan syariah di Banten mampu memberi kontribusi terhadap pertumbuhan PDRB Banten sebesar 53\%. Kontribusi sisanya 47\% disumbangkan oleh sektor lain yang tidak dimasukkan dalam penelitian ini.

Rekomendasi yang bisa diberikan untuk meningkatkan determinasi peran perbankan syariah dalam perekonomian Banten, diantaranya:

1. Peningkatan penetrasi perbankan syariah di Banten dapat dilakukan dengan cara memanfaatkan office chanelling bank konvensional papan atas yang ada di Banten. Dengan mayoritas penduduk muslim, perbankan syariah dapat 
memainkan peran yang melebihi peran yang dimainkan bank konvensional di Banten.

2. Mendorong Pemerintah Provinsi Banten untuk menempatkan dana desentralisasi di bank syariah. Kehadiran Bank Jabar Banten Syariah menjadi alternatif bagi Pemprov Banten untuk mengalokasikan dana desentralisasi ke sektor-sektor produktif dengan tetap memperoleh imbal hasil yang kompetitif.

3. Instansi lain yang bisa didorong adalah peran Dinas Koperasi di seluruh kab/kota untuk mempermudah izin pendirian Koperasi Jasa Keuangan Syariah (KJKS). KJKS atau yang lebih dikenal dengan BMT memiliki kemampuan dalam hal menjangkau menjangkau masyarakat sampai lingkup terkecil yang tidak mampu dijangkau oleh bank-bank umum. Sudah banyak peran yang dimainkan oleh lembaga keuangan mikro syariah ini dan sudah banyak pula pengaruhnya bagi perbaikan ekonomi daerah.

4. Terakhir dan yang tidak kalah penting adalah mendorong Pemprov Banten untuk terlibat langsung dalam peningkatan kuantitas dan kualitas sumber daya manusia untuk memenuhi permintaan industri keuangan syariah. Misalnya dengan pemberian beasiswa bagi para pelajar atau sarjana yang ingin melanjutkan ke jenjang yang lebih tinggi dalam bidang ekonomi dan keuangan Islam. 


\section{PUSTAKA ACUAN}

\section{Buku dan Jurnal}

Dumairy, 1996. Perekonomian Indonesia. Jakarta: Erlangga.

Ilyas, Satori, 2011. Kontribusi Perkembangan Perbankan Syariah Terhadap Tingkat Pertumbuhan Ekonomi dan Kemiskinan di Indonesia, Tesis Magister, Program Pascasarjana, IAIN Syekh Nurjati Cirebon.

Pohan, Aulia, 2008. Potret Kebijakan Moneter Indonesia. Jakarta: Rajawali Pers.

Rahardja, Prathama, dan Mandala Manurung, 2006. Teori Ekonomi Makro; Suatu Pengantar. Jakarta: LPFEUI.

\section{Artikel dan Makalah}

Andriansyah, Yuli, "Kinerja Keuangan Perbankan Syariah di Indonesia dan Kontribusinya bagi Pembangunan Nasional”, www.academia.edu.

Rama, Ali, “Analisis Kontribusi Perbankan Syariah Terhadap Pertumbuhan Ekonomi Indonesia", http://lisensiuinjkt.files.wordpress.com.

Rusydiana, Aam, Muhammad Syafii Antonio, "Peranan Ekonomi Syariah dalam Pembangunan Daerah", http://www.aamslametrusydiana.com.

Wahyono, Budi, "Analisis Prospek Kontribusi Ekonomi Syariah di Indonesia”, http://ekonomisyariah.info/blog.

Hakiem, Hilman, "Bank Syariah dan Pertumbuhan Ekonomi Bangladesh", Republika (Jakarta), 28 Juni 2012.

\section{Laporan dan Arsip}

Bank Indonesia, “Statistik Perbankan Syariah Desember 2013”, www.bi.go.id. , “Kajian Ekonomi Regional (KER) Banten Triwulan IV 2013", www.bi.go.id. 